\title{
HOTS EVALUATION INSTRUMENTS IN INDONESIAN LANGUAGE TEXTBOOKS
}

\author{
Imam Safi'i, Yeni Witdianti, Wini Tarmin, Prima Gusti Yanti \\ Graduate School of Indonesian Language Education, Universitas Muhammadiyah Prof. Dr. HAMKA, Jakarta, Indonesia \\ Jalan Warung Jati Barat, Kalibata, Pancoran, Jakarta Selatan 12740, Indonesia \\ Corresponding Author: imamsafii2077@uhamka.ac.id
}

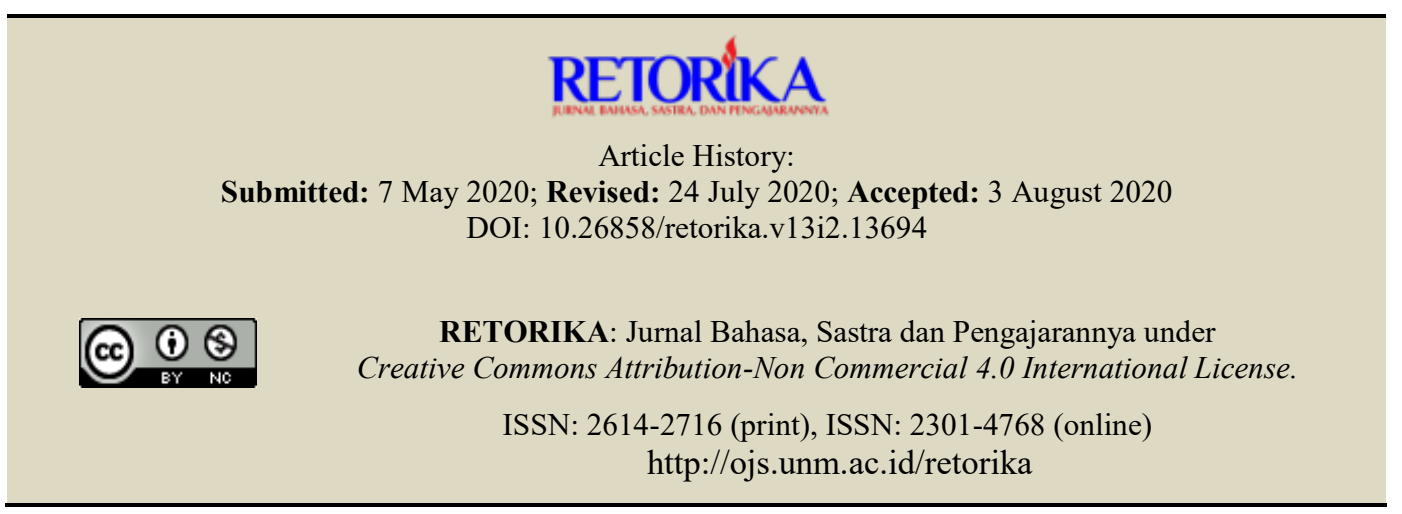

\begin{abstract}
This article reports on the results of a R \&D study on standard evaluation instruments used to measure students' higher-order thinking skills (HOTS) in Indonesian Language textbooks for the tenth-grade students registered in the academic year of 2019/2020. A qualitative approach to data collection and data analysis was employed. The identification of the research object was carried out by coding various data about the diversity of standard evaluation instruments of HOTS by examining the operational words used and the form of competency measured. The data were analyzed with regard to the level of tendency towards the measurement of certain aspects of thinking. Based on the findings of the research, it can be seen that HOTS contained in Indonesian textbooks class X are already diverse; however, the percentage of diversity is not yet proportional. The aspects include creative thinking (28.3\%), critical thinking (37.2\%), problem solving (18.6\%), and decision making $(15.9 \%)$ of all evaluation instruments analyzed. A less proportional percentage of each of these aspects shows that the utilization of HOTS standard evaluation instrument development criteria has not been maximally pursued.
\end{abstract}

Keywords: Diversity, HOTS, instruments, evaluation

The ability to think at a higher level is one's ability to solve various problems that require more careful and complex ways of thinking. The ability to think at a high level among students needs to be pursued through several things. Among them is through the procurement of Indonesian language textbooks containing various HOTS standard evaluation instruments, namely in the form of creative, critical thinking, problem solving, and making decisions. The evaluation instrument is one of the main media that can be used as an effort to dig up information about the level of learning success that has been carried out by the teacher. Through a good evaluation instrument, information about the level of student success can be valid so that it can be accounted for. Conversely, if the evaluation instruments used to extract information about students' success in 
learning are not good, then the results are also less valid and less accountable.

The standard evaluation instrument that is of the HOST standard or the measurement of high-level thinking skills was emphasized by Minister of Education and Culture Muhajdir Effendy in 2018. According to him, the weight on UNBK questions is indeed different from the usual assessment. Certain questions are made more difficult and require higher logical reasoning, or higher order thinking skills (HOTS), (Beritagar.id, 2018). High order thinking skills is a process of thinking of students in a higher cognitive level, (Safi'i \& Amar, 2019). The HOTS aspect of learning and assessment can positively influence student linguistic learning in terms of the learning process, performance in assessment, creativity, and motivation for learning,(Thnull, 2017).

In this regard, the international education system has also sought to define the types of skills that are considered important for increasing prosperity and well-being, (Murphy, Bianchi, Mccullagh, \& Kerr, 2013). Higher-order thinking skills are an important aspect of teaching and learning, (Yee et al., 2015). Learning oriented to higher order thinking skills can increase students' creativity. This is in line with opinionMay, Yunos, Othman, Hassan, \& Tze, (2012), that generating ideas is a thinking skill activity that requires high-level creative thoughts and actions. Learning oriented towards higher order thinking skills is also able to develop students' critical thinking skills. Critical thinking has a central role in learning, (McPeck, 1981; Beyer, 1987; Stupple et al., 2017; Safi'i \& Muljono, 2018).

Furthermore, what about the diversity of evaluation instruments found in Indonesian textbooks? Textbooks are one of the learning media that play an important role in the world of education.(Wahyuningtias, 2017). Textbooks are also very important for learning media in traditional classroom-based settings. This is very much in line with the learning system which is mostly implemented in Indonesia. Textbook learning resources contribute well to low and medium level independent learning that involves basic to intermediate cognitive processes, such as remembering, understanding, applying, and analyzing,(Lau et al., 2017). In addition, language learning textbooks have the potential to not only be a language learning guide, but can be a platform for introducing cultural diversity and tolerance as well as a medium for integrating knowledge across disciplines.(Huang, 2019).

So far, there has not been much comprehensive review of the quality of textbooks and the evaluation instruments contained therein, especially those relating to HOTS standard evaluation instruments in textbooks. Some studies of evaluation instruments that are HOTS-standard in textbooks are mostly partial and only deal with one of the teaching materials in Indonesian. For example, Pengembangan Instrumen Penilaian Berbasis Kemampuan Berpikir Tingkat Tinggi (HOTS) Untuk Pembelajaran Teks Resensi Pada Siswa Kelas XI SMA Negeri 5 Binjai Development of Assessment Instruments Based on High-Level Thinking Ability (HOTS) for Learning Text Review in Class X Public High School 5 Binjai Students' (Fatmaira, 2018), Pengembangan Instrumen Penilaian Teks Deskripsi Berbasis Higher Order Thinking Skills (HOTS) Siswa Kelas VII SMP Swasta Methodist Charles Wesley Medan, Development of a Description Text Assessment Instrument Based on Higher Order Thinking Skills (HOTS) Class VII Students Methodist Charles Wesley Private Middle School, (Sianturi, 2000), and Pengembangan Instrumen Pengetahuan (Kognitif) Berbasis HOTS pada Materi Teks Anekdot Kelas X SMA Negeri 1 Tanjungtiram, 'HOTS-Based Knowledge (Cognitive) Instrument Development on Class X Anecdotal Text Material of SMA Negeri 1 Tanjungtiram' (Matondang, 2019).

The study and development of HOTS standard evaluation instruments relating to one aspect of teaching materials is important to do. However, some of the studies and developments are still very minimal because they only relate to one particular aspect of teaching material. As a result, it cannot be used as a basis for drawing general conclusions related to the quality of evaluation instruments contained in textbooks. Therefore, a thorough review of evaluation instruments that are HOTS standard in the textbook must be carried out. This is important to do in order to obtain a comprehensive picture of the quality of HOTS standard evaluation instruments found in the textbook. Finally, an overview or information about the quality of the textbook will be obtained.

Based on these statements, this article is intended to present the results of a comprehensive 
study of the evaluation instruments contained in one of the Indonesian textbooks intended for high school students. This is because the role of textbooks is very important and strategic as stated by Huang, (2019), namely as a platform to introduce cultural diversity and tolerance as well as a medium to integrate knowledge across disciplines. Likewise, evaluation instruments in textbooks, in addition to being used as training material or enriching students' knowledge can also be used as a very effective medium for measuring students' level of understanding, and can even be used as a medium to enhance students' high-level thinking skills. This is in line with the findings of Hadar, (2017), that if the textbook provides an opportunity for students to engage in assignments that demand a higher level of understanding, students will have a higher score. Through textbooks and quality evaluation instruments can also be used as an effective media to foster a sense of student responsibility as expressed by Korkmaz \& Sadiye, (2014), that based on contemporary learning theory students are responsible for their own learning process.

Furthermore, can be explained, that the identification of the diversity of evaluation instruments with HOTS standards in the textbook can be divided into four categories, namely creative thinking, critical thinking, problem solving, and making decisions. The identification of evaluation instruments relating to critical thinking aspects refers to the concept of Torrance Test of Creative Thingking from Torrace as quoted by Stewart (2007) and Kim (2011), that the characteristics used to measure creativity tests in TTCT include fluency, authenticity (fluency) origanility), flexibility and elaboration. Fluency is the number or results of responses in the form of answers from respondents that are relatively relevant to the questions expressed in the evaluation instruments. Authenticity (origanility) is an evaluation instrument that is able to stimulate ideas or unique ideas. Flexibility in the TTCT creative test category is an evaluation instrument with a variety of ideas that can be well developed. While elaboration is an evaluation instrument in the textbook that is able to detail the ideas developed.

Characteristics of the critical thinking aspects used by researchers refer to several special abilities, namely analyzing arguments, inference, evaluating, and solving problems. Analyze arguments examine ideas or identify arguments developed in evaluation instruments. The inference is to suspect several alternatives or draw conclusions deductively or inductively, while the purpose of evaluating this component is that the evaluation instruments in the textbook are able to justify the procedure or are able to stimulate respondents to be able to give reasons in answering the evaluation instruments. Furthermore, the diversity of HOTS from problem solving or problem solving identified refers to the standard problem solving of Krulik and Rudnick (1993), which consists of the ability to read or understand a problem, exploration, Decision making refers to the common opinion (2001), which consists of identifying objectives, gathering information, comparing alternatives, and deciding. Various the data findings that have been identified based on various categories will then be calculated percentage to see diversity and trends.

Through this study, it is hoped that data will be obtained about the diversity of HOTS standard evaluation instruments contained in the Indonesian textbook. Information about the diversity of HOTS standard evaluation instru-ments contained in the textbook is very useful for teachers to be able to choose more appropriate teaching materials as a medium of learning to improve higher order thinking skills among students. For developers of instructional materials so that, the results of this study are also very useful as one of the foundations for compiling the instruments contained in textbooks to be more quality and have a proportional diversity of mea-surement aspects. Thus it will be used as a medium to develop students' thinking abilities optimally in order to be able to solve more com-plex problems. This is in line with what was stated by Gube \& Lajoie (2020), that to develop in a rapidly changing society, students must be able to think more flexibly or complexly.

\section{METHOD}

The data source in this research was Indonesian textbook grade $\mathrm{X}$ high school published by Tiga Serangkai Solo. The data analyzed were a number of evaluation instruments contained in the textbook. This study used qualitative approach using observation techniques. Creswell (2014) argues that through observation techniques the researcher directly observes research objects in a manner then records various findings 
related to the research focus and sub-focus. According to Creswell (2014), the research procedures that can be done are (1) identifying the object of research, (2) explaining various types of data that have been collected, and (3) discussing the results of research.

At the stage of identifying the research object, the researcher did the coding of various data related to standard evaluation instruments of HOTS and their variety. Identification of diversity is done by examining the operational words used as well as the form of bills or competencies that were measured through the evaluation instruments. The stage of explaining various types of data that had been collected was done by describing various data that had been analyzed and then determining the tendency of the aspects measured in the evaluation instrument. Furthermore, at the discussion stage, various data that had been found were interpreted and reviewed by relating to several relevant theories. The determination of the diversity of standard evaluation instruments of HOTS contained in the textbooks was based on the following criteria.

\section{FINDINGS AND DISCUSSION}

\section{Findings}

This results and discussion section contains (1) findings and discussion of evaluation tools for aspects of creative thinking, (2) findings and discussion of evaluation instruments for critical thinking aspects, (3) findings and discussions of evaluation instruments for aspects of problem solving, and (4) findings and discussion of instruments evaluating aspects of decision making.
Based on the analysis that has been done, there are a number of data regarding the diversity of HOTS standard evaluation instruments in Indonesian textbooks for grade $\mathrm{X}$ high schools published by PT Tiga Serangkai. The number of evaluation instru-ments on Indonesian textbooks analyzed is as much 60 items of essay test type or description. Essay tests or descriptions are spread evenly in the semester I and semester II, each of which consisted of 30 items. These data are presented in the following table.

Table 1. HOTS Standard Evaluation Instrument Criteria

\begin{tabular}{lll}
\hline HOTS Category & \multicolumn{1}{c}{ Criteria } \\
\hline Critical thinking & - analyze arguments \\
& - inference \\
& - evaluate \\
& - problem solving \\
\hline Think creatively & - smoothness \\
& - authenticity \\
& - flexibility \\
& - elaboration \\
\hline Problem solving & - read or understand a \\
& problem \\
& - exploration \\
& - choose a strategy \\
& - reviewing \\
\hline Make decision & - identify the purpose \\
& - gathering information \\
& - compare alternatives \\
& - deciding \\
\hline
\end{tabular}

Table 2. Diversity of HOTS Standard Evaluation Instruments

\begin{tabular}{ccc}
\hline Instrument Evaluation Category & Total & Percentage \\
\hline Creative thinking & 32 & $28.3 \%$ \\
\hline Critical thinking & 42 & $37.2 \%$ \\
\hline Problem solving & 21 & $18.6 \%$ \\
\hline Make decision & 18 & $15.9 \%$ \\
\hline
\end{tabular}

HOTS Instruments Category Creative Thinking

Based on a study of 60 evaluation instruments contained in Indonesian textbooks, there were 32 valuation instruments in the category of creative thinking. This is marked by several instructions to students to compile or develop something that demands student creativity.Here are a fewexampleabout the category of creative thinking contained in the evaluation instrument in the intended textbook.

(1) Buatlah sebuah paragraf yang berisi pernyataan pendapat tentang keber- 
sihan lingkungan! (soal no. 7, hlm. 55). 'Make a paragraph containing statements of opinion about environmental cleanliness! (question no. 7, p. 55).

(2) Ubahlah penggalan hikayat "Bayan Budiman" pada nomor 24 ke dalam bentuk cerpen! (soal no. 25, hlm. 125). 'Change the piece of the story "Bayan Budiman" on number 24 to the form of a short story! (about question no. 25, p. 125)'.

(3) Buatlah sebuah puisi bertema Fenomena Gadget dengan menggunakan diksi dan majas yang tepat. Berilah judul yang menarik! (soal no. 55, hlm. 246) 'Make a Gadget Phenomena themed poem using the right diction and form. Give an interesting title! (about question no. 55, p. 246)'.

Problem number 7 contains aspects of creative thinking because the instruction questions in number 7 are able to stimulate students to describe ideas or ideas in the form of opinions. In addition, in developing their opinions, students will certainly consider variations and details of ideas or ideas developed so that they become an opinion or opinion. Likewise the case with question number 25 is also an example of a problem that contains aspects of creative thinking because the problem is able to stimulate students to come up with a unique idea and be able to bring up variations of ideas proposed or developed through short stories. Problem number 55 describes all the characteristics of aspects of creative thinking in the form of fluency, authenticity, and elaboration.

\section{HOTS Instruments Category Critical Thin- king}

Furthermore, evaluation instruments relating to aspects of critical thinking. Measurement of critical thinking skills contained in the evaluation instruments in the textbook is very dominant, as many as 42 questions from the 60 evaluation instruments analyzed. The example questions containing aspects of critical thinking are as follows:

(4) Buatlah sebuah paragraf yang mendeskripsikan tentang tumbuh-tumbuhan atau binatang. Terapkan beberapa in- dera untuk menghidupkan deskripsi yang kalian buat! (Soal no. 2, hlm. 28) 'Make a paragraph describ-ing plants or animals. Apply a few senses to animate the description you made! (Problem no. 2, p. 28)'

(5) Argumentasi merupakan alasanalasan yang digunakan untuk mendukung terhadap pernyataan pendapat. Buatlah tiga contoh kalimat argumentasi dengan topik "Pentingnya Kebersihan Lingkungan Sekolah”! (Soal no. 14, hlm. 60) 'Arguments are the reasons used to support the statement of opinion. Make three example sentences of the argument on the topic "The Importance of School Environment Cleanliness"! (Problem no. 14, p. 60)'

(6) Buatlah sebuah teks eksposisi yang menyoroti masalah penggunaan gadget di kalangan masyarakat masa kini! (Soal no. 27, hlm. 132) 'Make an exposition text that highlights the problem of using gadgets in today's society! (Problem no. 27, p. 132)'

Problem number 2 is categorized as critical thinking because through the instruction the question will indirectly make students do several activities at once, namely identifying arguments, drawing conclusions deductively or inductively. Simultaneously will evaluate the choice of ideas or arguments that will be used in preparing paragraphs to describe the plants or animals. Likewise with questions number 14 and 27.

\section{HOTS Instrument Category Problem Solving}

Findings of problems that have aspects of problem solving existas much 21 questions out of 60 questions studied. The example questions that contain aspects of HOTS problem solvingis as follows:

(7) Susunlah kerangka teks anekdot yang bertajuk ekonomi atau politik! (soal no. 19, hlm. 84) 'Arrange an anecdotal text framework titled economic or political! (questions no 19, p. 84)'

(8) Kembangkan kerangka karangan tersebut menjadi teks anekdot yang lengkap komponen strukturnya! (soal no. 20, hlm. 84) 'Develop the outline of the composition into an anecdotal text 
complete with structural components! (question no. 20, p. 84)'

(9) Bacalah petikan hikayat berikut dengan baik! Buktikan disertai bukti pendukung bahwa penggalan hikayat tersebut menggambarkan nilai budaya pada masyarakat lama! (Soal no. 23, hlm. 125) 'Read the following saga passages carefully! Prove it along with supporting evidence that the fragment of the saga illustrates the cultural value of the old community! (questin no. 23, p. 125),

The above problem falls into the category of HOTS problem solving because problem number 19 instructs students to solve the problem in the form of adjusting the anecdotal textual framework with the proposed theme entitled economic or political. Then in question number 20 students are instructed to explore the framework of an essay into an anecdotal essay whose structural components are complete. Problem number 23 represents some of thestandard characteristics of problem solving, namely exploring, adjusting, and reviewing supporting evidence about the cultural values that exist in fragments of saga.

\section{HOTS Instrument Category Making Decisions}

Based on criteria predetermined identified 18 questions containing aspects of making decisions or $15.9 \%$ of all evaluation instruments analyzed. The example problem solving problems are as follows.

(10) Carilah majas dan imaji yang terkandung dalam puisi tersebut disertai bukti pendukung! (Soal no. 52, hlm. 246) 'Look for the forms and images contained in the poem with supporting evidence! (question no. 52, p. 246)'

(11) Teks cerita ulang biografi memiliki struktur tertentu, seperti: judul, orientasi, urutan peritiwa, dan reorientasi. Buatlah teks cerita ulang biografi yang dapat menunjukkan bagian orientasi! Pilihlah tokoh yang paling dikagumi! (Soal no. 47, hlm. 222) 'The biography story text has a certain structure, such as: title, orientation, event sequence, and reorientation. Make a biography story text that can show the orientation part! Choose the most admired character! (question no. 47, p. 222)'

(12) Tentukan makna puisi tersebut, kemudian buatlah parafrasenya! (Soal no. 59, hlm. 252) 'Determine the meaning of the poem, then make a paraphrase! (question no. 59, p. 252),

The three examples of questions above are included in the category of questions that contain aspects of HOTS making decisions because they contain instructions to students to decide. Question number 52 contains instructions for deciding what majaji or image contained in the poem is then supplemented with supporting evidence. Questin number 47 instructs students to decide on the figure chosen and admired in the biographical text illustrated in the previous problem. Through question number 59, students are instructed to decide the meaning of the poem and then paraphrase the poem.

\section{Discussion}

\section{HOTS Instruments Category Creative Thin- king}

Creative thinking is one component of $21 \mathrm{st}$ century skills that is highly emphasized by the government. This is evidenced by the publication of the 21st Century Curriculum Implementation Manual for Curriculum 2013 by Directorate of High School Development (Sutanto, 2017). Based on the large number of evaluation instruments used to measure students' abilities from the aspect of creative thinking indicate, that the compiler of the evaluation instruments in the textbook has tried to proportionally accommodate what is emphasized by the government related to the development of one of the 21st century skills. This is important to do, remember the development of creativity is seen as an integral part of the learning process, (Gajda, Karwowski, \& Beghetto, 2017; Kaufman \& Beghetto, 2009; Runco, 2003; Gralewski, 2018). In addition, creativity is also the key to encourage innovation, (Horkoff, Maiden, \& Asboth, 2018).In today's global competetive world, innovation is necessary, (Wijaya et al., 2019). Therefore, students as future agents must be honed by their creativity and innovation through the provision of exercises or evaluation instruments that demand the emergence of these creative and innovative powers. 
Furthermore, how is the relationship between the results of this study with previous research? In an article, Efendi, (2009) states that textbooks are part of a very important and meaningful learning tool in stimulating, advancing, and educating students. Based on the statement he has quoted, based on the World Bank report (1989) in Indonesia, it shows that the level of ownership of textbooks is correlated with student achievement. Starting from the statement, it seems to be increasingly clear, that through the provision of evaluation instruments in the textbook, the author in this case has a very strong desire to position the textbook as a very strategic medium in achieving learning objectives.

The findings of research on the HOTS standardized evaluation instrument used to measure students' creativity. This, as well as can be used to answer one of the probabilities of the low quality of education in Indonesia that was indicated by Seguin, (1990) cited by Mudzakir (2010), that one of the causes isthe absence of instructional material, especially textbooks, which, if any, is inadequate and not adapted to class needs.

Diverse thinking skills of students who demand creative thinking skills must indeed be pursued through evaluation instruments contained in textbooks. Creativity is the accumulation of a variety of skills, both affective and psychomotor. This is in line with the opinions of Indriana, et al. (2015), thatcreativity in the affective domain relates to aspects of internal values, while creativity in the psychomotor aspect relates to how a person produces original and innovative products in solving problems. This is important to strive for, given the ability to think creatively is an accumulation of several other thinking skills. A person is able to think creati-vely, of course it must be preceded by a critical attitude, motivation to solve problems, as well as making appropriate decisions about the follow-up on the problems he faces.

\section{HOTS Instruments Category Critical Thinking}

Critical thinking is a mental activity carried out using steps in the scientific method, namely: understanding and formulating problems, gathering and analyzing necessary and reliable information, formulating presumptions and hypotheses, testing hypotheses logically, drawing conclusions carefully, making conclusions evaluating and deciding something that will be believed or something that will be done, as well as predicting the consequences that might occur, (Abdullah, 2013).The measurement of ability that directs and requires students to think critically in the evaluation instruments in the Indonesian textbook studied is very dominant when compared to other HOTS aspects, which is 42 questions or $37.2 \%$ of the total evaluation instruments. A large number of evaluation instruments developed shows that through these textbooks students are highly emphasized so that their critical thinking skills can be truly honed.

Many, identification evaluation instruments are categorized as critical thinking because not a few evaluation instruments that have the same characteristics with other categories. For example, data (7 p. 50), (25 p. 125), and (55, p. 246) can be identified into creative thinking as well as critical thinking. In addition to having the characteristics of measuring students 'creative thinking abilities, the data is also characteristic to measure students' critical thinking ability, which is in the form of analyzing arguments, inferences, namely predicting alternatives or drawing conclusions deductively or inductively, and evaluating or justifying procedures with reasons.

Based on the findings of the data also shows, that there is a very serious effort from the compiler of the textbook to fulfill the role of the textbook as stated by Rohmawan (2020), that the textbook is used as a primary source in learning that contains knowledge, skills, and aspects attitude. In addition, textbooks must also provide stimulus to students to get used to thinking critically and creatively. The existence of a diversity of evaluation instruments used to measure students' critical thinking skills in Indonesian textbooks for high school grade X issues PT Tiga Serangkai Solo. This can also answer the statement from Muslich (2010) which has been quoted by Rahmawati (2015). According to him, the increasing need for textbooks as learning material must be balanced by improving the quality of textbooks.

\section{HOTS Instrument Category Problem Solving}

The probelem-solving instrument is related to the avaluation instrument citeria for the development or measurement of student creativity. Quoting the opinions of Sulistyowati \& Sugiman 
(2014); Wijayanti \& Sungkono (2017), who have combined the terms creative and problem solving explain that creative problem solving is a process, method, and system approach to problems in imaginative ways to produce effective solutions.

Giving training to students to solve various problems that demand problem solving will train students to be more careful in understanding and analyzing various problems they face. Student logic will also be honed. He will elaborate on many problems with various critical questions, such as what, why, and how the problem can arise before he finally able to solve the problem. This is in line with what Santrock (2010) said, that problem solving is finding the right way to achieve a goal. Given the importance of developing students 'thinking skills in solving problems, it is imperative that evaluation instruments in textbooks also explore students' abilities. Therefore,

The instrument of problem solving categorized in the Indonesian textbook for class X published by PT Tiga Serangkai is 21 or $18.6 \%$ of the total number of questions. If viewed in terms of the benefits of the development of problem categorized solutions to the development of student competencies and refer to the criteria of Krulik and Rudnick (1993), which consists of the ability to read or understand problems, exploration, choose strategies, adjust, and review are certainly still not optimal when compared with other aspects of thinking.

Increasing the ability of students to solve problems through the provision of evaluation instruments contained in textbooks will make a significant contribution to student competence in facing various challenges in life.Conversely, efforts to develop students 'ability to solve problems will impact the lack of students' ability to withstand various life challenges they face. This is in line with the statement from Patnani (2013), that the inadequacy of the students' ability to solve problems will make it difficult for students to optimize their potential, both during the educational process and when applying knowledge in the world of work.

\section{HOTS Instrument Category Making Decisions}

Decision-making skills begin with other abilities. Gradually, as stated by Common (2001), decision making skills include identifying goals, gathering information, comparing alternatives, and deciding. Therefore, before making a deci- sion, students must go through several stages of thinking first, namely analysis, synthesis, creative and also critical.

The development of skills makes the competence in evaluation instruments in Indonesian textbooks less explored maximally, in this case only $15 \%$ of the total evaluation instruments. The ability of students to make decisions must be sought because there is a very close relationship with students' scientific thinking abilities. This is in line with what was expressed by Campbel, et al., (1997) cited by Widodo (2007), that there is a very close relationship between scientific thinking with decision making, especially when using logic rules and evidence to define problems, formulate and test hypotheses, and translate the results into action.

Many factor cause why evaluation instruments in textbooks used to explore students' ability to make decisions have not been optimally developed. These factors include; (1) textbook compilers may not understand the importance of developing students' competencies in making decisions, (2) utilizing different parameters about decision making competencies that must be developed in the preparation of evaluation instruments, and (3) can also be caused by the tendency of textbook authors to put more emphasis on developing other aspects of thinking, especially in this case aspects of critical thinking.

Decision-making skills are no less important than other HOTS thinking skills. Saran: By habituating the ability to think and act to make the right decisions, they will be able to develop positive character students. Students will get used to being careful in making decisions with a variety of logical considerations. In making others will not easily influence decisions students. It is also not easy to hesitate in setting the right choices or actions in solving the problems it faces. This is very relevant to Ratna's research results (2009), that achievement identity status has a significant influence on the self-efficacy of decision-making in career development. The right perception of a thing or problem will impact making the right decision (Martinus, 2011).

\section{CONCLUSION}

Based on the results of research on the diversity of HOTS standardized evaluation instru- 
ments contained in Indonesian language textbooks class X published by the Tiga Serangkai Solo, it can be seen that the instruments contained in the textbooks are already diverse. However, the percentage of diversity has not been proportionate and still places great emphasis on one particular aspect of thinking, namely critical thinking. The composition of the diversity of evaluation instruments contained in the textbook is aspects of creative thinking as much $28.3 \%$, critical thinking $37.2 \%$, problem solving aspects $18.6 \%$, and aspect make decisionas much $15.9 \%$ of all evaluation instruments analyzed. The proportion that is less proportional in each of these aspects shows that the utilization of criteria for developing HOTS standard evaluation instruments that refer to various aspects of creative thinking, critical thinking, problem solving, and decision making has not been maximally pursued.

The dominance of the spread of measurement in certain aspects of thinking will be less supportive of efforts to develop students' ability to think holistically because in real life students will be faced with a number of problems that re-

\section{REFERENCES}

Abdullah, I. H. (2016). Berpikir Kritis Matematik. Delta-Pi: Jurnal Matematika dan Pendidikan Matematika, 2(1).

Creswell, J. W. (2014). Rersearch Design Quantitative, Qualitative, and Mixed Methods Approaches (Fourth Edi). United Kingdom: SAGE.

Chrisnawati, H. E. (2007). Pengaruh Penggunaan Metode Pembelajaran Kooperatif Tipe STAD (Student Teams Achievement Divisions) terhadap Kemampuan Problem Solving Siswa SMK (Teknik) Swasta di Surakarta Ditinjau dari Motivasi Belajar Siswa. https://publikasi ilmiah.ums.ac.id

Dwyer, C. P., Hogan, M. J., \& Stewart, I. (2014). An integrated critical thinking framework for the 21 st century. Thinking skills and Creativity, 12, 43-52.

Efendi, A. (2009). Beberapa Catatan tentang Buku Teks Pelajaran di Sekolah. INSANIA: Jurnal Pemikiran Alternatif Kependidikan, 14(2):320333.

Fatmaira, Z. (2018). Pengembangan Instrumen Penilaian Berbasis Kemampuan Berpikir Tingkat Tinggi (HOTS) untuk Pembelajaran Teks Resensi pada Siswa Kelas XI SMA Negeri 5 Binjai (Doctoral dissertation). Medan: Unimed. quire complex thinking abilities. Efforts to develop students' thinking abilities in diverse and proportional ways through evaluation in textbooks are very important. Every aspect of thinking has a very significant contribution in developing students' thinking abilities. The more often confronted or trained students 'thinking abilities in diverse ways, the more skilled students' abilities in thinking. Thus, when faced with a variety of problems, students will be able to overcome them easily.

Although it relates to all evaluation instruments relating to teaching materials in textbooks, this research is still limited to one textbook published by one of the publishers. Therefore, data on the diversity of HOTS standard evaluation instruments extracted were more likely to be related to the textbook. A similar study that uses a wider range of Indonesian textbook data sources and a variety of publishers still needs to be done. Thus a more comprehensive picture will be obtained about the quality of evaluation instruments in them more extensive Indonesian textbook.

Gralewski, J., \& Karwowski, M. (2018). Are Teachers' Implicit Theories of Creativity Related to the Recognition of their Students' Sreativity? The Journal of Creative Behavior, 52(2): 156-167.

Gube, M., \& Lajoie, S. (2020). Adaptive Expertise and Creative Thinking: A Synthetic Review and Implications for Practice. Thinking Skills and Creativity, 35(August 2019), 100630. https:// doi.org/10.1016/j.tsc.2020.100630

Hadar, L. L. (2017). Studies in Educational Evaluation Opportunities to learn : Mathematics textbooks and students' achievements. Studies in Educational Evaluation, 55(October), 153-166. https: //doi.org/10.1016/j.stueduc.2017.10.002

Hidayat, S. R., Setyadin, A. H., Hermawan, H., Kaniawati, I., Suhendi, E., Siahaan, P., \& Samsudin, A. (2017). Pengembangan Instrumen Tes Keterampilan Pemecahan Masalah pada Materi Getaran, Gelombang, dan bunyi. Jurnal Penelitian \& Pengembangan Pendidikan Fisi$k a, 3(2): 157-166$.

Horkoff, J., Maiden, N. A., \& Asboth, D. (2019). Creative Goal Modeling for Innovative Requirements. Information and Software Technology, 106, 85-100.

Huang, P. (2019). Learning, Culture and Social Interaction Textbook interaction: A study of the 
Language and Cultural Contextualisation of English Learning Textbooks. Learning, Culture and Social Interaction, 21 (December 2018): 87-99. https://doi.org/10.1016/j.lcsi.20 19.02.006

Indriana, V., Arsyad, N., \& Mulbar, U. (2015). Penerapan Pendekatan Pembelajaran POE (PredictObserve-Explain) untuk Meningkat-kan Kemampuan Berpikir Kreatif Siswa Kelas XI IPA-1 SMAN 22 Makassar. Daya Mate-matis: Jurnal Inovasi Pendidikan Matema-tika, 3(1): 51-62.

Torrance Tests of Creative Thinking. Creativity Research Journal, 23(4): 285-295.

Korkmaz, M. O. K. \& S. K. (2014). Relationship Between the High School Students Perspectives on Study Skills and the Types of State High School In Terms of Some Variables, 152: 1029-1033. https://doi.org/10.1016/j.sbspro.2014.09.268

Krulik, S., \& Rudnick, J. A. (1993). Reasoning and Problem Solving: a Handbook for Elementary School Teachers. Allyn and Bacon.

Lau, K. H., Lam, T., Kam, B. H., Nkhoma, M., Richardson, J., Richardson, J., \& Richardson, J. (2017). SC. Computers \& Education. https:// doi.org/10.1016/j.compedu.2017.11.005

Matondang, C. E. H. (2019). Pengembangan Instrumen Pengetahuan (Kognitif) Berbasis HOTS pada Materi Teks Anekdot Kelas X SMA Negeri 1 Tanjungtiram, (Doctoral disser-tation). Medan: Unimed.

McCammon, I. 2001. Decision Making for Wilderness Leaders: Strategies, Traps and Teaching Methods. Proc. Wilderness Risk Manager's Conf. Oct, 26-28, 2001, Lake Geneva, WI, hal. 16-29

Mei, Y., Yunos, J., Othman, W., Hassan, R., \& Tze, T. (2012). The Needs Analysis of Learning Higher Order Thinking Skills for Generating Ideas, 59, 197-203. https://doi.org/10.1016/j.sbspro.201 2.09.265

Murphy, C., Bianchi, L., Mccullagh, J., \& Kerr, K. (2013). Scaling up Higher Order Thinking Skills and Personal Capabilities in Primary Science: Thinking Skills and Creativity, 10, 173188. https://doi.org/10.1016/j.tsc.2013.06.005

Mudzakir, A. S. (2010). Penulisan Buku Teks yang Berkualitas. Tersedia: online http://file. upi. edu.

Patnani, M. (2013). Upaya Meningkatkan Kemampuan Problem Solving pada Mahasiswa. Jurnal Psikogenesis, 1(2): 130-142.

Rahmawati, G. (2015). Buku Teks Pelajaran sebagai Sumber Belajar Siswa di Perpustakaan Sekolah di SMAN 3 Bandung. Edulib, 5(1).

Rohmawan, A. (2020). Aspek Berpikir Kritis dan Kreatif dalam Buku Teks Karya Mahasiswa. Basindo: Jurnal Kajian Bahasa, Sastra Indo-nesia, dan Pembelajarannya, 4(1): 32-44.

Rudnick, S. K. J. A. (1996). The New Sourcebook for Teaching Reasoning and Problem Solving in Junior and Senior High School. https://scholar. google.co.id/scholar

Rukismono, M. (2011). Pengaruh Perilaku Konsumen dalam Mengambil Keputusan Memilih Jasa Transportasi Udara Lion Air di Surabaya. Jurnal Kewirausahaan, 5(2): 1-9.

Runco, M. A., Millar, G., Acar, S., \& Cramond, B. (2010). Torrance Tests of Creative Thinking as Predictors of Personal and Public Achievement: A fifty-year Follow-up. Creativity Research Journal, 22(4): 361-368.

Safi'i, I \& Amar, F. (2019). Pelatihan Penyusunan Instrumen Evaluasi Berstandar HOTS bagi GuruGuru SD di Wilayah Banyudono. Abdi mas Dewantara, 2(2): 149-157. https://doi. org/10.30738/ad.v2i2.4176

Safi'i, I \& Muljono, H. (2018). Pelatihan Pembelajaran dengan Strategi Critical Thinking Question. Jurnal Abdi Masyarakat, 2(1). https://doi.org /10.30737/jaim.v2i1.237

Sawitri, D. R. (2009). Pengaruh Status Identitas dan Efikasi Diri Keputusan Karir Terhadap Keraguan Mengambil Keputusan Karir pada Mahasiswa Tahun Pertama di Universitas Diponegoro. Junal Psikologi. Undip.

Santrock, J. (2010). Psikologi Pendidikan (edisi kedua). Jakarta: Kencana Prenada Media Group.

Sianturi, L. P. (2000). Pengembangan Instrumen Penilaian Teks Deskripsi Berbasis Higher Order Thinking Skills (HOTS) Siswa Kelas VII SMP Swasta Methodist Charles Wesley Medan (Doctoral dissertation) Medan: Unimed.

Stewart, P. J. (2007). No Creative Child Left Behind: Using the Torrance Tests of Creative Thinking to Identify and Encourage Middle School Learners. International Journal of Learning, 14(1).

Sutanto, P. (2019). Panduan Implementasi Kecakapan Abad 21 Kurikulum 2013 di Sekolah Menengah Atas. https://scholar.google.co.id/scho lar

Thnull, N. (2017). Influence of Explicit Higher-Order Thinking Skills Instruction on Student's Learning of Linguistics. https://doi.org/10.10 16/j.tsc.2017.10.004

Wahyuningtias, H. (2017). Evaluasi Buku Teks Pelajaran Bahasa Jepang Tingkat Dasar "Minna No Nihongo." Jurnal Penelitian dan Evaluasi Pendidikan, 21(1): 11-20. Retrieved from http: //journal.uny.ac.id/index.php/jpep

Yee, M. H., Yunos, J., Othman, W., Hassan, R., Tee, T. K., \& Mohaffyza, M. (2015). Disparity of Learning Styles and Higher Order Thinking Skills among Technical Students. Procedia - 
Social and Behavioral Sciences, 204 (November 2014): 143-152.https://doi.org/10. 1016/j. sbspro.2015.08.127

Widodo, W. (2007). Keterampilan Pengambilan Keputusan. https://scholar.google.co.id/scholar

Wijaya, R. A., Qurratu'aini, N. I., \& Paramastri, B. (2019). Pentingnya Pengelolaan Inovasi dalam
Era Persaingan. Jurnal Manajemen dan Bisnis Indonesia, 5(2): 217-227

Wijayanti, S., \& Sungkono, J. (2017). Pengembangan Perangkat Pembelajaran Mengacu Model Creative Problem Solving Berbasis Somatic, Auditory, Visualization, Intellectually. Al-Jabar: Jurnal Pendidikan Matematika, 8(2): 101-110. 